\title{
Work Coordination as a Social Interaction Process in Nursing Staff Meetings
}

1 Eveliina Pennanen'

MA, Doctoral Student, Department of Communication, University of Jyvaskyla, Finland

I Leena Mikkola

PhD, Senior Lecturer, Department of Communication, University of Jyvaskyla, Finland

\begin{abstract}
Work coordination, which here refers to organizing, planning, discussing, and negotiating work, is done through social interaction. Because coordination is essential to work quality and well-being at work, it is important to understand the processes that construct work coordination. This study aims to understand work coordination as a social interaction process by analyzing social interaction in nursing staff meetings of a Finnish hospital. Observations and approaches of inductive and descriptive qualitative analysis were used to examine eight sequential nursing staff meetings that took place in 2012. The results indicate that work coordination consisted of sense-making information, sense-making action, managing emotions, and managing positions of employees. Work coordination constructs the social reality of the workplace both on the task level and the relational level. Understanding that work coordination is not only a task-oriented process that deals with organizing practical tasks and duties but is also a process of constructing positions and relationships in work communities helps to identify and understand the possibilities that social interaction and its practices, such as workplace meetings, offer. The findings can be applied in the organizational context to evaluate and develop workplace interactions.
\end{abstract}

\section{KEY WORDS}

Interpersonal communication / nurses / social interaction / work coordination / work quality

DOI

10.19154/njwls.v6i2.4970

\section{Introduction}

hange and growth in the health care sector is occurring throughout Europe, and the challenge of ensuring a sufficient amount of workforce is topical in the Nordic countries. The nature of nursing and the organizational structures of health care organizations, like hospitals, give rise to circumstances that are multifaceted. First, organizational structures, hierarchies, borderlines between professions, and the cultural and the functional differences even between the same professions working in different specialist areas make hospitals complex working environments with interaction structures that are unique; these kinds of structural dimensions and the need to adjust to work in

\footnotetext{
1 eveliina.s.pennanen@jyu.fi
} 
and between them may also burden employees (Ang et al., 2013; Apker, 2012; Barbour, 2010; Ray \& Apker, 2011). Second, nursing is physically demanding and often highly emotional. The demands inherent in nurses' work emerge in social interaction in the workplace (Apker et al., 2005). Nurses need to manage various tasks, roles, and emotions in their work, and all these aspects take place in social interaction with their colleagues, other employees, and patients and patients' relatives (Apker, 2012; Ray \& Apker, 2011).

According to a European survey, more than one-fourth of young registered nurses in Finland consider leaving nursing several times a month (Flinkman, 2014). Nurses' perception that it is difficult or impossible to affect unsatisfactory work conditions connects to their intention to leave their profession, but retention can be strengthened by providing nurses with processes in which they can participate in influencing their work and get supported, mentored, and orientated (Flinkman \& Salanterä, 2015). Work coordination is one essential aspect in which these kinds of processes can take place in social interaction in the workplace.

Work coordination can be approached from many perspectives and with a focus on various dimensions; it can be seen as a mixture of practical tasks or as a more abstract phenomenon such as leadership. As the subject can be defined and operationalized in many ways and on various levels, there is an extensive research literature on it. Work coordination has been approached from the viewpoint of taking care of or planning specific activities and tasks or practical processes at the workforce, and the emphasis is often on the end results of coordination instead of the process itself (e.g., Alfieri et al., 2011; Holliman et al., 2001; Liddicoat \& Taylor-Leech, 2014). Work coordination has also been viewed from a perspective in which societal themes, such as gender issues, are aspects that are studied in the context of organizing work (e.g., Nogueira et al., 2012) or from a perspective of a specific phenomenon, such as leadership (e.g., Larsson \& Lundholm, 2013). In this study, work coordination is viewed through communication: work coordination is examined as exchanging messages of organizing, planning, discussing, and negotiating work-related topics. Our aim is to describe and understand work coordination as a process of social interaction by analyzing how work coordination is constructed in nursing staff meetings of a hospital. Our research question is: What are the qualities of social interaction in the process of work coordination?

The research design of this study is qualitative: the data consist of observations of eight nursing staff meetings at a public Finnish hospital providing special care, and the work coordination that occurred in the social interactions of the participants was analyzed using approaches of inductive and descriptive qualitative analysis. These types of hospitals are part of the Finnish health care system; the municipalities are in charge of arranging the citizens' primary health care and also special health care needs to be provided (Kokkinen, 2012, p. 16). The large organizational size, multidimensional hierarchy, distribution of work based on specialization, and the high level of autonomy in experts' work create an interesting mixture of two reciprocal tensions: bureaucracy and expertise (Kokkinen, 2012, pp. 17-18).

\section{Background}

Work coordination connects closely to quality of work and well-being at work and becomes visible in social interaction processes and relationships of workplaces ${ }^{1}$. Its 
meaning in hospitals and other complex working contexts is essential on many levels. Work coordination is connected to both performing the work and creating employees' feeling of coping. For instance, detailed resource planning and effective management support nurse outcomes that include job satisfaction and intention to leave (Choi et al., 2013). Nursing management at the unit level and nurses' opportunities to participate in policy decisions or involvement in the internal governance of the workplace (for instance, various committees) are associated with workforce stability (Van Bogaerta et al., 2009). Being able to influence one's work creates a feeling of control, and nurses perceive that opportunities to participate in organizing their work promote their well-being (Breaux et al., 2008).

Consequently, work coordination as a social interaction process affects both collective and individual well-being by having an effect on work performance and offering possibilities to influence one's own work or decisions that are made concerning it (see Robertson \& Flint-Taylor, 2009). In a hospital context, the position of nurses in coordination processes becomes especially challenging and interesting; nurses may face the challenge of juggling the need to influence their work and adjusting to the limits that the organizational structures create (Wright et al., 2013).

The theoretical background of this study rises from the tradition of interpersonal communication that approaches human communication as a dynamic process that is a complex mixture of individual and social processes (Berger, 2014). In this study, social interaction and interpersonal communication are viewed as social processes of people exchanging messages in attempting to create shared meanings and accomplish social goals (Burleson, 2010, p. 151). It is a process by which the social world is sense-made (Berger, 2014, p. 9). The approach of this study also interlocks with the idea of assessing organizations from a process viewpoint: meanings are created in sense-making processes (Hernes \& Maitlis, 2010; Weick, 2001). Sense-making is seen as an ongoing, retrospective process in which people aim at creating order and making sense about themselves and situations that they have been involved; the individuals' experiences can be shaped into meaningful patterns in social interaction (Weick, 2001).

This study aims to understand work coordination as a social interaction process by analyzing social interactions in the processes of coordinating work at hospital staff meetings. Earlier studies have often approached work coordination from the viewpoint of individuals by examining individuals' own experiences and perceptions of coordination and its consequences. Understanding how work coordination is performed in workplaces is necessary to understand not only the outcomes of the coordination process but also the process and its significance for work quality and its multiple dimensions.

\section{Methods}

\section{Data collection}

The study was conducted qualitatively by observing and analyzing nursing staff meetings in one operational unit of a Finnish hospital. This particular organization was selected after contacting the hospital district to find participants and the hospital and the work unit were interested in cooperation. The observation method was chosen because the aim was to understand the interaction processes, and observation enables the interaction phenomena to be examined in the way that they authentically appear (Frey et al., 2000). 
The approach for data collection was inductive. In the data collection phase, the goal was to observe the dynamics of social interaction of the staff meetings. The research aim and the research question were then formed on the basis of observations. During the observations, work coordination started to appear as a multifaceted, interesting process, and the focus of the research was defined to concentrate on it. The data consisted of eight nursing staff meetings, which were held weekly in the department. These meetings are part of the nursing management structure, and their agenda includes work-related and administrative matters. They are the only occasions that bring all the nursing staff working in the same shift together at one time. The meetings were observed and audio-recorded during the autumn of 2012. The data collection was finished after regularities started to emerge (see Lincoln \& Cuba, 1985).

A researcher was present but did not take part in the discussions. The observed meetings lasted 10-55 minutes; the aggregate duration of the recorded audio data was 5 hours 10 minutes. There were 21-28 employees at each meeting, and the meetings were chaired by the head nurse, who is also the immediate superior of nurses, or one of the head nurse's deputies. The attendees consisted of registered nurses, practical nurses, office secretaries, a departmental secretary, and employees who assist nursing work. All these employees are named in this article as nursing staff because they either did nursing work or their work closely supported it. Some of the nurses were in charge of certain nursing practices. The attendees' backgrounds varied from being a new trainee to having many years of work experience. Due to the nature of shift work and the need to provide nursing care during the meetings, it was common for staff to leave or arrive in the middle of the meeting. Consequently, the number of employees attending each meeting fluctuated.

The ethical principles of respecting the autonomy of research subjects, avoiding harm, and privacy and data protection (National Advisory Board on Research Ethics, 2009) were followed during the research. Extensive information about the research project was given to the participants both verbally and in writing before beginning the data collection. Participation was voluntary; participants signed a written consent indicating their willingness to be involved in the research. Participants were also informed they could contact the researchers at any time during and after the process of data collection with further questions. The data were collected during the working hours in the normal staff meetings of the department, so participating in the data collection sessions was not a separate task for the participants. The anonymity of the research subjects was ensured, and the data were stored on a password-protected hardware. The subjects were treated with respect both during the data collection and while reporting the findings.

\section{Data analysis}

After the recorded material was transcribed, the interactions in which work-related themes were discussed, negotiated, organized, or planned were examined and episodes were selected for analysis. Interaction episodes were defined as a communicative phase in which at least two people participated verbally or nonverbally (Marková et al., 2007). Episodes were differentiated as distinct when the topic of interaction changed.

For the analysis, approaches of inductive qualitative analysis (Graneheim \& Lundman, 2004) and qualitative description (Sandelowski, 2010) were used to examine the functions of social interaction. First, the social interaction functions that took place in 
the interaction episodes were identified by interpreting the primary functions that the expressions had. An interaction function can, for instance, be asking for an opinion, sharing information, or showing friendliness (Bales, 1950; Laapotti \& Mikkola, 2015). The expressions were labeled and inductively categorized according to their functions. Second, the main functions in which work coordination was performed were identified and named by combining related functions according to their meanings. In this way, we gained the theoretical level.

The analysis concentrated on verbal communication because the data setting did not enable analyzing nonverbal communication with sufficient precision. For the unit of analysis, we used an expression that was identified as a meaning unit. Interpretations were made according to the meaning of the message; categorization depended on the content of the text in which the function was performed. The interpretations during the analysis were made by the first author, and the interpretations were discussed in a research group familiar with the data. The interpretations of the data were similar. To analyze the data, we used the qualitative analysis software program ATLAS.ti (see Friese, 2014). The data examples presented in the results section were translated into English from Finnish, and the authors are responsible for all translations of recorded verbal interactions at the meetings. The information that could lead to identifying the research participants, such as names of employees, departments, and treatments, was anonymized or removed from the transcripts.

\section{Results}

The nursing staff meetings partly followed traditional meeting format and practices and were partly more informal. Interaction was led by the chair; the head nurse and her deputies chaired the meetings in turns, and discussions were mostly opened and closed by the head nurse or her deputies. The topics of the interaction in the meetings concerned the working environment and equipment; work arrangements, such as working hours and responsibilities; challenging work situations, such as patient safety incidents; and current topics at the workplace, such as various projects and patient feedback. Much of the conversation between the head nurse and her deputies concerned organizational performance, and the nursing staff participated more actively in discussions about themes that concerned their own work, for example, nursing practices.

From the perspective of social interaction, work coordination that took place in the nursing staff meetings consisted of (1) sense-making work-related information, (2) sense-making action, (3) managing emotions, and (4) managing positions. These processes consisted of structuring a shared understanding about the meaning of work-related information, negotiating the accepted way to act and operate at work, negotiating the acceptance of emotions at work, and positioning the members in the work community and negotiating their roles.

\section{Sense-making work-related information}

Sense-making work-related information was social interaction in which the meaning of information was negotiated. In this way, a shared understanding about the information 
at work was constructed. The information that was sense-made was given by the organization or higher levels of management and was reported in the department meetings. Information could also be shared by a participant of the meeting.

The negotiation processes included asking for information, sharing information, asking for opinions, sharing opinions, seeking confirmation, and confirming and denying significance (see Tab. I).

Table I Sense-making information: Functions and data examples

Sense-making information

\begin{tabular}{lll}
\hline Function & Description & Data example \\
\hline $\begin{array}{l}\text { Asking for } \\
\text { information }\end{array}$ & $\begin{array}{l}\text { Requesting that someone gives } \\
\text { information about a particular activity }\end{array}$ & $\begin{array}{l}\text { DI: How was it, Tom? Did you have a } \\
\text { meeting about that other town's... You } \\
\text { had that treatment meeting on one day? }\end{array}$ \\
\hline $\begin{array}{ll}\text { Sharing } \\
\text { information }\end{array}$ & $\begin{array}{l}\text { Giving information or briefing about a } \\
\text { particular activity (unbiased reporting) }\end{array}$ & $\begin{array}{l}\text { N4:The town was mentioned, yes, that } \\
\text { the plan to take the equipment should } \\
\text { be started to set them up there, but.... } \\
\text { this wasn't discussed that thoroughly } \\
\text { [DI:Yeah], so something like that... }\end{array}$ \\
\hline
\end{tabular}

Asking for opinion Asking for an opinion about a particular HN: How does this sound to you? theme

\begin{tabular}{lll}
\hline Sharing opinion & $\begin{array}{l}\text { Expressing an opinion (evaluative or } \\
\text { personal viewpoint) }\end{array}$ & $\begin{array}{l}\text { N2: I think it might be good if we could } \\
\text { get that expert to brief us about it. }\end{array}$ \\
\hline
\end{tabular}

Seeking Seeking confirmation about information HN:Well, Anne said then that the departconfirmation or understanding a particular theme ment should have a meeting about it. So shall we, or should someone else, participate project that... For me, the issue of the project did not clear up, whether it involves the whole work community or only some individuals... [HN turns to $\mathrm{S}$ ] did you understand something about that discussion... or about her monologue?

\begin{tabular}{lll}
\hline $\begin{array}{l}\text { Confirming } \\
\text { meaning }\end{array}$ & $\begin{array}{l}\text { Expressing that given information, } \\
\text { perception, or understanding was } \\
\text { correct or relevant }\end{array}$ \\
\hline $\begin{array}{ll}\text { Denying } \\
\text { significance }\end{array}$ & $\begin{array}{l}\text { Expressing an opinion or doubt that the } \\
\text { information was correct or relevant }\end{array}$ & $\mathrm{Dl}$ Saturdays and Fridays. \\
& $\mathrm{N} 4:$ And in the evenings, we did those \\
& operations, too. \\
& $\mathrm{Dl}$ : Friday evenings and Saturdays. \\
& $\mathrm{D} 2:$ But we will now check the amount and \\
& HN: It must have been during the working \\
& hours. It cannot have been outside the \\
& working time because nobody can be \\
& forced to work outside of that time. \\
&
\end{tabular}

$\mathrm{D}=$ deputy, $\mathrm{HN}=$ head nurse, $\mathrm{N}=$ nurse, $\mathrm{S}=$ departmental secretary. 
In the negotiating processes, information and opinions were often asked and shared by the head nurse or her deputies and especially by the one who was chairing the meeting. They thus had a major role in the sense-making process. Nursing staff asked for information mostly by asking for specifics and gave information and opinions when asked to do so. After requesting information or opinions, negotiating processes continued with information or opinion sharing or information asking, if specifications were asked. Often the functions of asking and sharing information appeared in a questionsingle answer format in which information was requested and then shared and then the meeting moved to the next topic. In this manner, the information was processed but not negotiated or sense-made collectively. In the negotiating processes in which specifics were requested, more aspects were discussed and often with more participants, which made the process more collective. Sense-making information was emphasized in the work coordination interaction, which connects to the task-oriented nature of the nursing staff meetings.

The processes of sense-making information also included seeking confirmation and confirming and denying significance (see Table 1). All participants sought confirmation from an individual, for example, from a staff member who either knew or could have known more about the topic, or from the collective (all those present at the meeting). The confirmation was sought for the information, perception, or understanding, and then its meaning was either confirmed or denied. Confirming was often performed by the head nurse or one of her deputies or a staff member who had information about the topic handled because of their position (e.g., a nurse in charge), specific expertise (e.g., being a member in a project group), or direct work experience of the specific task (e.g., experience on certain treatments).

The relevance of information, perception, or understanding could also be denied. The participant's position, expertise, or experience dictated the role of denier in these episodes; the one who had power originating either from their organizational status (e.g., being a superior) or earned status (e.g., having long-term experience) had a right to deny. Denial was, however, rarely used. The outcomes of the negotiation processes of sense-making information were often consensus-oriented. Sense-making information was a way to structure a shared understanding about the meaning of information. Thus, it can also be seen as a structuring process of the shared reality of the work community.

\section{Sense-making action}

In the nursing staff meetings, the justified course of actions was constructed by sensemaking action. In these processes, the right ways to act or operate at work and different kinds of work situations were negotiated. The processes of sense-making action involved both the past and the future. In sense-making the past, actions that had taken place in the past were explained and reasoned, for example, what had happened, and why in a high-risk situation with a patient. In sense-making the future, the meanings of the future actions and particularly changes involving the hospital organization, the department, or the staff were structured. Sense-making thus not only structured the appropriate actions and working procedures in the workplace but also helped to manage the past and future of the organization and work community. 
Sense-making action in interaction consisted of collectively remembering, negotiating future actions, seeking justification for action, justifying action, and rejecting the relevance of action (see Tab. II).

Table II Sense-making action: Functions and data examples

\section{Sense-making action}

\begin{tabular}{lll}
\hline Function & Description & Data example \\
\hline Collectively & Seeking to find a & DI: But let's check that thing first so it won't then \\
remembering & common understanding & surprise [HN: mmm] us [HN:Yes] \\
& about something that & D2: But didn't we do those operations during weekends \\
& happened in the past & then? \\
& HN:Yes, but these are tasks performed outside the \\
& working [D2: yeah] hours. \\
& D2:Well yes, but so was that, we did it in the same way \\
& at that time \\
& N5: But did you get then some extra days off or how \\
& did it work?
\end{tabular}

\begin{tabular}{|c|c|c|}
\hline $\begin{array}{l}\text { Negotiating } \\
\text { future actions }\end{array}$ & $\begin{array}{l}\text { Seeking shared } \\
\text { understanding about } \\
\text { something that will } \\
\text { happen in the future }\end{array}$ & $\begin{array}{l}\text { N2: - - So we then would have those units over there in } \\
\text { the future. } \\
\text { N3: So they would then be on the same floor [HN: yes] } \\
\text { in that building [HN: in the same] } \\
\text { HN:Yes, like in the same floor, or somewhere else in the } \\
\text { same place... At least I don't know how to decide who } \\
\text { would have one room less than present. I would say let's } \\
\text { take it from someone else. I would not give any of our } \\
\text { rooms away. }\end{array}$ \\
\hline
\end{tabular}

Seeking justification Seeking acceptance for action for one's behavior

or performance
N3: May I say something at this point? I was a part of this [DI: oh] situation [DI: okay]. So there were three nurses that came to tell us to just do the treatment there [DI: okay], and then this one particular nurse who was a total outsider just came later to say this thing that

\begin{tabular}{|c|c|c|}
\hline Justifying action & $\begin{array}{l}\text { Expressing allowance } \\
\text { to participate or that } \\
\text { the action is accepted } \\
\text { or important }\end{array}$ & $\begin{array}{l}\text { DI: Okay, so the nurses promised [N3: yes] that you can } \\
\text { do the treatment there in the hallway - - - Well, we need } \\
\text { to write a comment that some nurses promised that it } \\
\text { can be conducted there [N3: yes] - - - }\end{array}$ \\
\hline Rejecting relevance & $\begin{array}{l}\text { Showing that the } \\
\text { action is not relevant } \\
\text { or accepted }\end{array}$ & $\begin{array}{l}\text { DI: He said that guy working there, Daniel, I don't } \\
\text { remember his surname, so he said that their head nurse } \\
\text { had briefed him about his duties, and he will bring the } \\
\text { patients from Building A for us when it is closed, like it is } \\
\text { now. And if they are going to Departments } 19 \text { or } 20 \text {, he } \\
\text { will take the patients there. But this was a patient of the } \\
\text { cancer department the other day, so who will then take } \\
\text { them? } \\
\text { HN: BUT it is our duty to take patients to Departments } \\
19 \text { and } 20 \text {. We will not leave the patients in here. }\end{array}$ \\
\hline
\end{tabular}

$\mathrm{D}=$ deputy, $\mathrm{HN}=$ head nurse, $\mathrm{N}=$ nurse, $\mathrm{S}=$ departmental secretary. 
Collectively remembering was a process performed by both the head nurse and her deputies and staff members in which past actions were constructed. This was performed by negotiating how something was done in the past, for instance, how a new treatment practice was done earlier or what had been agreed about certain topics in other forums of the hospital. In this way, a shared understanding about the past was created. Negotiating future actions and possibilities included planning for future activities and examined forthcoming aspects of work. This was especially performed by the head nurse and her deputies and included negotiating how something should or could be done in the future or how a certain topic was going to be forwarded at the departmental or organizational level. Staff members also participated in the negotiating processes, but mostly only when their opinion was asked. In the negotiating processes, a shared understanding or a vision about the future was constructed.

Sense-making the action was also processed by seeking justification and justifying action, which means that the acceptance of a past or a forthcoming action was negotiated. Seeking justification for action was sought for a particular activity or a perception of a particular activity that had been done or was going to be done. Although all participants sought justification for their actions, the nursing staff was most active in this context. Seeking justification for one's action was expressed by giving reasons and explaining why one had acted in a certain way, for example, in a challenging work situation. Often someone else at the meeting then justified the action by expressing that it was or is an accepted way to act. The justifiers were mostly the head nurse or her deputies, usually the one chairing the meeting. Hence, the position of the participant seemed to dictate the role of the justifier; the one who had the power to lead the interaction of the meeting also had the power to justify the past and future actions. The relevance of the action could also have been rejected, but this rarely happened.

Seeking justification for action enabled responsibility to be transferred. Responsibility was transferred by explaining the reasons behind the action or behavior. In these reasoning processes, the reasons were argued with organizational features (e.g., hospital hierarchy by reasoning that a particular activity was done because somebody who was in charge, such as a physician, had made a request), own position (e.g., there was no information about a certain topic because it had not been received even though a request had been made), and nature of the work (e.g., the frenetic nature of the nursing work forcing certain actions). Responsibility was also taken especially by the head nurse and the deputies when they expressed that a particular activity happened because of their own mistake; in this way, they sought justification for their action.

\section{Managing emotions}

The appropriateness of emotions at work was constructed in social interactions of work coordination by managing emotions. These processes negotiated the kind of emotions that are accepted and entitled at work. Managing emotions consisted of expressing and justifying emotions (see Tab. III). 
Table III Managing emotions: Functions and data examples

\begin{tabular}{lll}
\hline Managing emotions & & \\
\hline Function & Description & Data example \\
\hline Expressing emotions & $\begin{array}{l}\text { Describing the emotions } \\
\text { that had taken place at work }\end{array}$ & $\begin{array}{l}\text { N9:Yeah, but it is interesting, that when this kind } \\
\text { of thing happens to oneself [HN: yes], you are } \\
\text { like 'damn' [gives a laugh], and you are not like } \\
\text { anymore 'well yeah, it happens' [N2: no]. When it } \\
\text { happens to you, it is quite... it is a very traumatic } \\
\text { experience, I can assure you [N: yes, it is] }\end{array}$ \\
\hline Justifying emotions & $\begin{array}{l}\text { Expressing that the emotion } \\
\text { is accepted or important }\end{array}$ & $\begin{array}{l}\text { N5: But at least I can say that the way you took } \\
\text { care of that occasion afterwards... that even } \\
\text { though you thought that you were a ... that you } \\
\text { thought someone else should have taken care } \\
\text { of the situation, I think you were, like, extremely } \\
\text { professional in that situation. }\end{array}$ \\
\hline
\end{tabular}

$\mathrm{D}=$ deputy, $\mathrm{HN}=$ head nurse, $\mathrm{N}=$ nurse, $\mathrm{S}=$ departmental secretary.

The participants of the meetings expressed their emotions that they had had in earlier work situations. Expressing the emotions included seeking justification for emotions, and it was performed by excusing or emphasizing the emotions. Excusing was expressed by describing how the emotions were a reason for certain behavior or actions that had taken place at work. Emotions, for example, had prevented them acting in a way that was expected, such as one had forgotten to do something because of confusion about a sudden unexpected incident. Emphasizing was used to describe the significance of the emotions for one's behavior or the occurrence; for instance, anxiety with a patient could be described to be a reason for behaving in a certain way. In these ways, a right to have certain emotions was sought, and this was also a way of reasoning things that happened. The nursing staff was in the majority in seeking justification for their emotions, but in some cases so too did the head nurse and her deputies.

By expressing their emotions, the participants often had someone else justify why they had a right to feel a certain way. The justifier was often a peer; a nurse could justify other nurses' emotions, and the head nurse and her deputies could justify each other's emotions. Also, the head nurse and her deputies, usually the one chairing the meeting, often justified nurses' emotions, as they were also leading the interaction of the meetings. The processes of expressing emotions and justifying them also connect to positioning oneself in the work community. The position of being a peer was constituted, while the emotions were justified by positioning oneself on the same level with the one expressing their emotions. This was done by expressing the normality of those emotions, for instance, by expressing that 'all of us feel that way sometimes.'

In the processes of managing emotions, the appropriateness of emotions at work was negotiated and the accepted emotional level of work was structured: the social interaction of managing emotions structured a shared understanding about what kind of emotions are justified and so to say right to feel or show at work. 


\section{Managing positions}

The positions of the participants were managed in the social interaction of work coordination processes by negotiating the rights to participate and expressing belongings or nonbelongings into different groups and subgroups of the workplace. The positions were managed by seeking justification to participate, justifying or rejecting the relevance of participation, and describing belonging or nonbelonging to a group (see Tab. IV).

Table IV Managing positions: Functions and data examples

\begin{tabular}{|c|c|c|}
\hline \multicolumn{3}{|l|}{ Managing positions } \\
\hline Function & Description & Data example \\
\hline $\begin{array}{l}\text { Seeking justification to } \\
\text { participate }\end{array}$ & $\begin{array}{l}\text { Seeking permission to participate in } \\
\text { the meeting by looking for permission } \\
\text { to talk or looking for the right to talk } \\
\text { about a certain topic }\end{array}$ & $\begin{array}{l}\text { N6: I have a couple of things to } \\
\text { say, but I won't talk for long. }\end{array}$ \\
\hline Justifying participation & Expressing permission to participate & $\begin{array}{l}\text { HN: Thank you, Tom, it is good to } \\
\text { recap these things every now } \\
\text { and then. }\end{array}$ \\
\hline $\begin{array}{l}\text { Rejecting relevance of } \\
\text { participation }\end{array}$ & $\begin{array}{l}\text { Showing that participation is not } \\
\text { relevant or accepted }\end{array}$ & $\begin{array}{l}\text { NI: How about Department } 14 \\
\text { and the preparations for those } \\
\text { operations and } \\
\text { N2:That is all clear already!! }\end{array}$ \\
\hline $\begin{array}{l}\text { Describing belonging to or } \\
\text { exclusion from a group }\end{array}$ & $\begin{array}{l}\text { Expressing one's in-group or } \\
\text { out-group position }\end{array}$ & $\begin{array}{l}\text { N8: Well, I have said this to new } \\
\text { doctors coming into our hospital, } \\
\text { but it doesn't seem to register with } \\
\text { all of them } \\
\text { N7:Yeees, they should brush up on } \\
\text { this thing a little bit, too. }\end{array}$ \\
\hline
\end{tabular}

$\mathrm{D}=$ deputy, $\mathrm{HN}=$ head nurse, $\mathrm{N}=$ nurse, $\mathrm{S}$, departmental secretary.

The nursing staff was in the majority in seeking justification for their participation, but the head nurse and her deputies also occasionally sought justification for participation when not in charge of chairing the meeting. Justification to participate was sought from the chair of the meeting, who then justified or rejected it. The process of seeking the right to participate involved asking for an opportunity to talk or diminishing the importance of either the topic or the participation, which was done by underrating the topic or the significance of one's own participation, for instance, by expressing that the topic was a familiar one, but the participant still wanted to say something about it. The relevance was then justified or rejected. Justifying was done by expressing that the person was allowed to talk or that the topic was allowed or significant, and rejecting was done by pointing out that the topic was not significant. Justifying or rejecting enabled or disabled participation and thus also constructed the positions of the participants by defining what kind of participation, in which contexts, and by whom is relevant. 
Managing positions in the meetings also involved the interactions that connect to constructing sense of belonging to or being excluded from certain groups. The sense of either belonging or not to a group was expressed by referring to 'we' and 'them', which could refer to peer groups (e.g., expressions of 'our nurses' or 'nurses of other departments'), management (e.g., expressions of 'them' referring to management of higher levels in hospital administration or head nurse and deputies referring to 'we as superiors'), or other employee groups (e.g., expressions of 'them' referring to physicians). The expressions of belonging or nonbelonging could also connect to institutions (e.g., expressions of 'their department' or 'our hospital').

\section{Limitations}

This study took a new kind of an approach into work coordination by viewing it as a social interaction process and as a result gained new understanding about work coordination as a process that is constructed in the social interaction at work. When it comes to evaluating the trustworthiness of the study, credibility, transferability, and conformability were evaluated (Denzin \& Lincoln, 2011; Lincoln \& Cuba, 1985; Merriam, 2009).

While evaluating the credibility of the data, the effect of data collection on research subjects and the coverage of the data describing the studied subject were taken into account (Lincoln \& Cuba, 1985). The data collection was conducted in naturally occurring settings. A researcher acting as a nonparticipant outsider observer of the interaction of a group situation may have an effect on the behavior of the group's participants, but the participants become accustomed to the observer as the period of observation continues (Lindlof \& Taylor, 2002). The study's observation period lasted for approximately four months and was conducted once a week, but the period included some weeks that the meetings were not held. In the first meeting, there were fewer interaction episodes than in later meetings, possibly because of the researcher's presence. However, when asked, the participants described the observed meetings to have been customary. In comparing the interaction that took place in the meetings, the differences between the meetings were small. The possibility to observe authentic meetings of a workplace and hence gather rich data were strengths of this study.

While evaluating the credibility of the study, it is important to recognize that qualitative analysis is interpretation, and thus the interpreter always adds something to the original material (Denzin \& Lincoln, 2011; Graneheim \& Lundman, 2004; Sandelowski, 2010; Willig, 2014). The credibility of the analysis was strengthened by a thorough familiarization with the functional perspective, conducting the analysis systematically, and negotiating the interpretations with a research group. The data examples presented in the tables help the reader to evaluate the analysis. The trustworthiness of the study was strengthened by evaluating the applicability of the results, which can be done in a qualitative study by evaluating whether the results could be transferred into another context (Lincoln \& Guba, 1985). The objective of this study was to understand the studied phenomenon, as it takes place in a specific context and thus not to gain generalized information (see Frey et al., 2000).

However, it is noteworthy that work coordination is conducted in all types of organizations and in many workplace meetings and also in informal work situations. Although a hospital is a unique working environment, other organizations can be viewed 
as having similar features in work coordination processes as those found in a hospital context. Chair-led staff meetings that are organized regularly to inform and handle topical work-related themes are part of the communicative practices of many organizations. The findings of this study can thus be applied into work coordination strategies and practices of other organizations by acknowledging that the contextual features, such as the nature of the work, affect the interaction and hence need to be taken into account. The conformability of the findings is strengthen by earlier research in which the processes of work coordination have been seen as important in organizational processes and especially from interpersonal communication research that sees the communication as an essential aspect of constructing shared meanings and realities (see Berger, 2014; Burleson, 2010). The findings' connections into organizational theories, such as Weick's (2001) organizational sense-making, also strengthen the conformability of the study.

\section{Discussion}

Work coordination was approached inductively in this study. Our findings show that work coordination is a multifaceted social interaction process that consists of not only sense-making information but also sense-making and managing action, emotions, and relational positions at work. Work coordination is thus much more than just planning and organizing work performance; at the same time, although the social interaction processes construct work coordination, they construct the social reality of work by formulating the accepted way to be a member of a work community and the accepted ways to act, feel, and understand at work. This finding reflects Weick's (2001) viewpoint about organizational sense-making, which is described as an ongoing process in which people try to collaboratively create order and make sense, for themselves and others, of past situations in which they have been involved. The results of the present study suggest that also work coordination processes are a way of establishing order and responding to the need to find a shared way of understanding both task and relational dimensions of work and workplace.

Rodwell and Munro (2013) suggest that employees' opportunity to participate and thus affect the aspects of their own work is part of well-being construction at work. The results of the present study show that sense-making work-related information is a collective process in which confirmation and complements are sought and given while negotiating a shared understanding about the information. In these processes, the employees can participate in influencing their work and constructing the reality of it. Jünger et al. (2007) implicate that collective information management can promote the shared understanding about the common goals and procedures of work and also contribute to employees' identifying with work. Thus, sense-making work-related information can also connect to quality of work as well as the well-being of employees and work communities.

Earlier research has identified that many social interaction processes connect to aspects of constructing well-being at work. In the context of health care, the well-being of nurses is explained by social interaction phenomena, such as collegial support (Utriainen et al., 2015), feedback (Christiansen, 2008), creating and maintaining interpersonal relationships among nurses (Gurková et al., 2012), and the possibility of having an effect on one's work (Rodwell \& Munro, 2013) (see also Utriainen \& Kyngäs, 2009). 
According to findings of the present study, these kinds of processes can take place in the work coordination processes, but it is important to understand the meaning of the interaction in a more profound way. Consequently, as the findings of this study implicate, work coordination can be approached as consisting of processes in which the reality of work and work community are constructed both on the task level and on the relational dimensions. This viewpoint may also explain why the aspects of work coordination have been shown to be an essential aspect of well-being studies; while work coordination is a collective process of negotiating positions and relationships as well as creating meanings for work, it is much more than just organizing practical tasks and duties.

Seeking and giving confirmation were highlighted in the processes of sense-making work-related information. This finding has many dimensions. First, seeking and giving confirmation can be seen as ways of reducing uncertainty at work, as they are processes in which the responsibility of offering correct or accepted information can be shared. On the other hand, if one continuously needs to seek confirmation or if information is not seen as factual until someone else confirms it, these processes may also place stress on employees. For example, according to Ervin and Bonito (2014), one's willingness to participate may diminish if one is being repetitively rejected, and Breaux et al. (2008) suggest that the lack of sense of being able to control one's work may threaten wellbeing at work. Consequently, to support well-being construction via work coordination, equal possibilities for participation and acceptance of attendees' various viewpoints are required. Interaction itself is not enough, but it is the quality of interaction that counts.

The results of this study show that sense-making work-related information is not only coordinating task-related topics but also coordinating the relationships in the workplace. The aspects, such as whose information is relevant, correct, or accepted, are part of the relational level of the workplace. Seeking and giving confirmation can construct and maintain the power structures of the work community by outlining an individual's position. Here, the concept of positioning refers to the construction and development of participants' roles and parts, and thus an individual's position can be viewed as a combination of rights and duties that justify performing and acting in a certain way (Harré \& van Langenhove, 1999; Hirvonen, 2013). By enabling or disabling participation in meetings, the positions of participants are managed, while it is made clear what kind of information and who can share that information is allowed or accepted. The head nurse and her deputies dominated the processes of sense-making work-related information. This communication pattern enables the superiors to have a greater influence on deciding which and whose interpretations become right or relevant. Hence, it is also important to consider the level of understanding that is shared among the work community or whether the processes support the creation of shared understanding of the management.

Sense-making action in the interaction of work coordination processes constructs the justified course of acting and operating at work. Collectively remembering is a process in which the reality of work is retrospectively negotiated, whereas the forthcoming actions are made reasonable and understandable while negotiating future actions. The processes of reflecting on the past and negotiating the future can be explained by the idea of organizational sense-making, which sees sense-making as a retrospective process; situations are made rationally accountable by individuals, and remembering and looking back at times are fundamental resources of meaning (Weick, 2001). In the social interaction of the meetings, different kinds of episodes were reasoned by reflecting on what had happened and why or what will happen at the workplace. The interaction that enables employees to

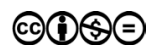


find meanings to the past and to the future may support managing uncertainty at work if the interaction promotes creating shared understandings and visions of work, workplace, and organization or employees' positions in the context of those.

In the processes of sense-making action, seeking justification and justifying actions are used to transfer or take responsibility. In these ways, the responsibility is negotiated, and a shared understanding of the correct ways to act at work is created. It seems that these responsibility aspects taking place through work coordination processes are interwoven with the typical feature or structure of a hospital culture in which the employees need to know who is responsible for every activity (Apker, 2012; Wright et al., 2013). In the performance of a basic function of a hospital organization, that is, taking care of the patients, it is important to know who is responsible for particular patient-care activities. Interestingly, this seems to become visible in work coordination processes as well. Apker et al. (2010) describe this phenomenon by implicating that the interaction practices taking place in the clinical workplace can transfer to other circumstances at the workplace. When evaluating or developing the workplace interaction of health organizations, it is important to consider the pros and cons of the basic principles of medical work that reflect on the organization's other processes, such as administrative work. Interaction practices that are expedient while treating a patient may not always be the most suitable practices in other work situations.

The framework of appropriated or accepted emotions at work is constructed while managing emotions in the work coordination processes. Many earlier studies have emphasized the importance of handling emotions in nurses' work because of the emotional nature of nursing. For instance, a phenomenon that connects closely to managing emotions is emotional labor, which is a process in which employees manage their real feelings so that the atmosphere for clients remains caring and safe (Hochsild, 1983; Karimi et al., 2014; Miller, 2007). It is an interesting finding that the nursing staff meetings and work coordination taking place in them offer an arena for emotional aspects, even though the objectives of the meetings may officially be defined to be highly taskcentered. The freedom to express various feelings in the work community is part of collegial support, which also links to nurses' well-being construction (Utriainen et al., 2015). Thus, in health care organizations, it is important to acknowledge the employees' need for controlling emotions and support employees managing the emotional demands of the work.

\section{Conclusions}

From the viewpoint of quality of work, it is important to understand both the significance of the outcomes of work coordination, which can, for example, be well-planned work practices, and the significance of the process itself. It is noteworthy that the processes of work coordination take place on many levels; they can connect to the task or relational level or be interwoven with both simultaneously, as the results of this study suggest. For instance, sense-making work-related information not only includes negotiating task-oriented topics but also the relationships of the workplace are constructed and maintained while positioning whose information is relevant and whose is not. Rather than separating or polarizing these levels, it is beneficial to see work coordination as a comprehensive process in which the shared realities are constructed. 
Furthermore, it is important to understand that the processes of work coordination do not take place only on an individual level but also occur on interpersonal and group levels. These aspects are essential when evaluating and developing the social interaction processes and practices in working life. The findings also connect to well-being construction, and while earlier research has often approached well-being at work from the viewpoint of individuals' own perceptions and experiences of their personal well-being or well-being in general, it would be interesting to look closely into how the processes are constructed in the social interaction. Hence, future research could aim to understand how the individuals' experiences and perceptions of their well-being at work are created in the social interaction of work coordination processes and also in other social interaction processes at work.

This study enables understanding work coordination as a process that has more dimensions than just organizing practical tasks and duties. In organizations and workplaces, it is important to pay attention to the quality of interaction, not only the amount of it or sufficient arena enabling it. With the findings of this study, the communicative nature of work coordination is made more visible. The findings can help organizations, work communities, and people working in them to acknowledge the multifaceted nature of communication processes and practices, such as meetings, taking place at work, and thus enable them to see the important and wide-ranging nature of these phenomena. This can help employees understand and value more the administrative side of the work, which, for example, in the health care context may sometimes be seen as an extra duty or a less significant aspect. The acknowledgement of the importance of these processes can help the management of organizations to enable expedient conditions for practices in which the processes can take place. In the context of organizational development, the findings can be applied, for instance, in workplace interaction training. Moreover, from the societal perspective, the results of this study can be utilized while aiming to support employee retention in the health care industry.

\section{Acknowledgments}

The present article is based on the first author's doctoral dissertation under preparation, supervised by the second author. This study was funded by The Finnish Work Environment Fund (112304) and University of Jyvaskyla, Faculty of Humanities. The study was approved by the Central Finland Hospital District. The ethical principles of the Finnish Advisory Board on Research Integrity (2015) were followed.

\section{Note}

${ }^{1}$ The literature searches were done in interdisciplinary journal databases. The searches concentrated on peer-reviewed journal articles.

\section{References}

Alfieri, A., Tolio, T. \& Urgo, M. (2011) A project scheduling approach to production planning with feeding precedence relations. International Journal of Production Research 49(4): 995-1020. doi: http://dx.doi.org/10.1080/00207541003604844. 
Ang, S. H., Bartram, T., McNeil, N., Leggat, S. G. \& Stanton, P. (2013) The effects of high-performance work systems on hospital employees' work attitudes and intention to leave: A multi-level and occupational group analysis. The International Journal of Human Resource Management 24(16): 3036-3114. doi: http://dx.doi.org/10.1080/09585192.2013.775029.

Apker, J. (2012) Communication in Health Organizations. Cambridge, UK: Polity.

Apker, J., Mallak, L. A., Applegate, E. B., Gibson, S. C., Ham, J. J., Johnson. N. A. \& Street, R. L. (2010) Exploring emergency physician-hospitalist handoff interactions: Development of the handoff communication assessment. Annals of Emergency Medicine 55(2): 16-70. doi: http://dx.doi.org/10.1016/j.annemergmed.2009.09.021.

Apker, J., Propp, K. M. \& Ford, W. S. (2005) Negotiating status and identity tensions in healthcare team interactions: An exploration of nurse role dialectics. Journal of Applied Communication Research 33(2): 93-115. doi: http://dx.doi.org/10.1080/00909880500044620.

Bales, R. F. (1950) Interaction Process Analysis. A Method for the Study of Small Groups. Cambridge: Addison-Wesley.

Barbour, J. B. (2010) On the institutional moorings of talk in health care organizations. Management Communication Quarterly 24(3), 449-456. doi: http://dx.doi.org/ $10.1177 / 0893318910370269$.

Berger, C. (2014) Interpersonal communication: Historical foundations and emerging directions. In Interpersonal Communication (C. R. Berger ed), pp. 33-26. Berlin: Walter de Gruyter GmbH.

Breaux, D. M., Meurs, J. S., Zellars, K. L. \& Perrewe, P. L. (2008) Burnout in health care: When helping hurts. In Handbook of Stress and Burnout in Health Care (J. R. B. Halbesleben ed), pp. 39-50. New York, NY: Nova Science Publishers.

Burleson, B. R. (2010) The nature of interpersonal communication: A message-centered approach. In Handbook of Communication Science (C. R. Berger, M. E. Roloff \& D. Roskos-Ewoldsen eds), pp. 145-163. 2nd ed. Thousand Oaks, CA: Sage.

Choi, S. P-P., Cheung, K. \& Pang, S. M-C. (2013) Attributes of nursing work environment as predictors of registered nurses' job satisfaction and intention to leave. Journal of Nursing Management (21)3: 429-439. doi: http://dx.doi.org/10.1111/j.1365-2834.2012.01415.x.

Christiansen, B. (2008) Good work - how is it recognised by the nurse? Journal of Clinical Nursing 17(12): 1645-1651. doi: http://dx.doi.org/10.1111/j.1365-2702.2007.02139.x.

Denzin, N. K. \& Lincoln, Y. S. (2011) Introduction: The discipline and practice of qualitative research. In The Sage Handbook of Qualitative Research (N. K. Denzin \& Y. S. Lincoln eds) pp. 1-19. 4th ed. Thousand Oaks, CA: Sage.

Ervin. J. \& Bonito, J. A. (2014) A review and critique of partner effect research in small groups. Small Group Research 45(6): 603-632. doi: http://dx.doi.org/10.1177/1046496414551027.

Finnish Advisory Board on Research Integrity. (2015) Ethical principles of research in the humanities and social and behavioural sciences. [online] Available at: <http://www.tenk. fi/en/ethical-review-human-sciences/ethical-principles> [Accessed September 7, 2015].

Flinkman, M. (2014) Young registered nurses' intent to leave the profession in Finland - a mixed method study. PhD thesis, University of Turku.

Flinkman, M. \& Salanterä, S. (2015) Early career experiences and perceptions - a qualitative exploration of the turnover of young registered nurses and intention to leave the nursing profession in Finland. Journal of Nursing Management 23(3): 1050-1057. doi: http://dx.doi.org/10.1111/jonm.12251.

Frey, L. R., Botan, C. H. \& Kreps, G- L. (2000) Investigating Communication. An Introduction to Research Methods. 2nd ed. Boston, MA: Allyn \& Bacon.

Friese, S. (2014) Qualitative Data Analysis with ATLAS.ti. 2nd ed. London: Sage.

Graneheim, U. H. \& Lundman, B. (2004) Qualitative content analysis in nursing research: concepts, procedures and measures to achieve trustworthiness. Nurse Education Today 24(2): 105-112. doi: http://dx.doi.org/10.1016/j.nedt.2003.10.001. 
Gurková, E., Čáp, J., Žiaková, K. \& Ďurišková, M. (2012) Job satisfaction and emotional subjective well-being among Slovak nurses. International Nursing Review 59(1): 94-100. doi: http://dx.doi.org/10.1111/j.1466-7657.2011.00922.x.

Harré, R. \& van Langenhove, L. (eds). (1999) Positioning Theory. Oxford: Blackwell Publishers.

Hernes, T. \& Maitlis, S. (2010) Process, sensemaking, and organizing: an introduction. In Process, Sensemaking, and Organization (T. Hernes \& S. Maitlis eds), pp. 27-37. Oxford: Oxford University Press.

Hirvonen, P. (2013) Positioning in an inter-professional team meeting: Examining positioning theory as a methodological tool for micro-cultural group studies. Qualitative Sociology Review, [e-journal] IX(4): 100-114. Available through: <http://www.qualitativesociologyreview.org/ENG/archive_eng.php> [Accessed October 6, 2015].

Hochscild, A. R. (1983) The Managed Heart: Commercialization of Human Feelings. Berkeley, CA: University of California Press.

Holliman, D. C., Dziegielewsk, S. F. \& Priyadarshi, D. (2001) Discharge planning and social work practice. Social Work in Health Care 32(3): 1-19. doi: http://dx.doi.org/10.1300/ I010v32n03 01.

Jünger, S., Pestinger, M., Elsner, F., Krumm, N. \& Radbruch, L. (2007) Criteria for successful multiprofessional cooperation in palliative care teams. Palliative Medicine 21(4): 347-354. doi: http://dx.doi.org/10.1177/0269216307078505.

Karimi, L., Leggat, S. G., Donohue, L., Farrell, G. \& Couper, G. E. (2014) Emotional rescue: the role of emotional intelligence and emotional labour on well-being and job-stress among community nurses. Journal of Advanced Nursing 70(1): 176-186. doi: http://dx.doi.org/10.1111/jan.12185.

Kokkinen, L. (2012) Työntekijät julkisten sairaaloiden rakennemuutostarpeiden synnyttäjinä ja rakennemuntosten seurausten kokijoina. (Employees create needs for and experience the effects of structural changes in public hospitals) $\mathrm{PhD}$ thesis, University of Tampere.

Laapotti, T. \& Mikkola, L. (2015) Kokousvuorovaikutuksen tehtäväkeskeiset funktiot sairaalajohtoryhmässä. (Message functions in hospital management group meetings) Työelämän Tutkimus 13(1): 38-55.

Larsson, M. \& Lundholm, S. E. (2013) Talking work in a bank: A study of organizing properties of leadership in work interactions. Human Relations 66(8): 1101-1129. doi: http://dx.doi.org/10.1177/0018726712465452.

Liddicoat, A. J. \& Taylor-Leech, K. (2014) Micro language planning for multilingual education: agency in local contexts. Current Issues in Language Planning 15(3): 237-244. doi: http://dx.doi.org/10.1080/14664208.2014.915454.

Lincoln, Y. S. \& Guba, E. G. (1985) Naturalistic Inquiry. Newbury Park, CA: Sage.

Lindlof, T. R. \& Taylor, B. C. (2002) Qualitative Communication Research Methods. 2nd ed. Thousand Oaks, CA: Sage.

Marková, I., Linell, P., Grossen, M. \& Orvig, A. S. (2007) Dialogue in Focus Groups. Exploring Socially Shared Knowledge. London: Equinox.

Merriam, S. B. (2009) Qualitative Research: A Guide to Design and Implementation. San Francisco, CA: Jossey-Bass A Wiley Imprint.

Miller, K. I. (2007) Compassionate communication in the workplace: Exploring processes of noticing, connecting, and responding. Journal of Applied Communication Research 35(3): 223-245. doi: http://dx.doi.org/10.1080/00909880701434208.

National Advisory Board on Research Ethics (2009) Ethical principles of research in the humanities and social and behavioural sciences and proposals for ethical review. [online] Available at: <http://www.tenk.fi/sites/tenk.fi/files/ethicalprinciples.pdf> [Accessed October 15, 2015]. 
Nogueira S., Lacomblez, M., Santos, M., Cunha, L. \& Castelhano J. (2012) The entry of women in predominantly male professions: when training supports the search of alternative ways of organizing work time. Work 41(1): 4650-2. doi: http://dx.doi.org/10.3233/ WOR-2012-0103-4650.

Ray, E. B. \& Apker, J. (2011) Stress, burnout, and supportive communication. A Review of research in health organizations. In The Routledge Handbook of Health Communication (T.R. Thompson, R. Parrot \& J. F. Nussbaum eds) 2nd ed, pp. 428-440. New York, NY: Routledge.

Robertson, I. T. \& Flint-Taylor, J. (2009) Leadership, psychological well-being, and organizational outcomes. In The Oxford Handbook of Organizational Well-being (S. Cartwright \& C. L. Cooper eds), pp. 159-179. New York, NY: Oxford University Press.

Rodwell, J. \& Munro, L. (2013) Well-being, satisfaction and commitment: The substitutable nature of resources for maternity hospital nurses. Journal of Advanced Nursing 69(10): 2218-2228. doi: http://dx.doi.org/10.1111/jan.12096.

Sandelowski, M. (2010) What's in a name? Qualitative description revisited. Research in Nursing \& Health 33(1): 77-84. doi: http://dx.doi.org/10.1002/nur.20362.

Utriainen, K. \& Kyngäs, H. (2009) Hospital nurses' job satisfaction: A literature review. Journal of Nursing Management 17(8): 1002-1010. doi: http://dx.doi.org/10.1111/j.13652834.2009.01028.x.

Utriainen, K., Ala-Mursula, L. \& Kyngäs, H. (2015) Hospital nurses' wellbeing at work: A theoretical model. Journal of Nursing Management 23(6): 735-743. doi: http://dx.doi. org/10.1111/jonm.12203.

Van Bogaerta, P., Clarkeb, S., Vermeyenc, K. Meulemansd, H. \& Van de Heyninge, P. (2009) Practice environments and their associations with nurse-reported outcomes in Belgian hospitals: Development and preliminary validation of a Dutch adaptation of the Revised Nursing Work Index. International Journal of Nursing Studies 46(1): 55-65. doi: http://dx.doi.org/10.1016/j.ijnurstu.2008.07.009.

Weick, K. E. (2001) Making Sense of the Organization. Malden, MA: Blackwell Publishing. Willig, C. (2014) Interpretation and analysis. In The SAGE Handbook of Qualitative Data Analysis (U. Flick ed), pp. 136-151. Thousand Oaks, CA: Sage.

Wright, K. B., Sparks, L. \& O'Hair, H. D. (2013) Health Communication on the $21^{\text {st }}$ Century. Malden, MA: Wiley-Blackwell. 